\title{
Creating an International Prison
}

Mary Margaret Penrose

Texas A\&M University School of Law, megpenrose@law.tamu.edu

Follow this and additional works at: https://scholarship.law.tamu.edu/facscholar

Part of the International Law Commons, and the Law and Politics Commons

\section{Recommended Citation}

Mary M. Penrose, Creating an International Prison, 38 Hous. J. Int'I L. 425 (2016).

Available at: https://scholarship.law.tamu.edu/facscholar/935

This Article is brought to you for free and open access by Texas A\&M Law Scholarship. It has been accepted for inclusion in Faculty Scholarship by an authorized administrator of Texas A\&M Law Scholarship. For more information, please contact aretteen@law.tamu.edu. 


\title{
CREATING AN INTERNATIONAL PRISON
}

\author{
Meg Penrose* \\ I. INTRODUCTION: MAKING THE CASE FOR AN \\ INTERNATIONAL PRISON \\ II. THE HISTORICAL APPROACH TO INTERNATIONAL \\ SENTENCING: FROM NUREMBERG TO THE \\ CoOPERATING STATES MODEL .................................. 432 \\ III. ShorTCOMINGS IN THE STATUS QUO ............................ 439 \\ A. The Lack of Cooperating States..............................439 \\ B. Conditions, Distance, Language, Security and \\ Cultural Distinctions ...............................................443 \\ C. Security ...................................................................450 \\ D. Rehabilitation, Release, and Reintegration ..............451
}

IV. Obstacles to CREating AN International PRISON ... 456

A. The Costs .........................................................457

B. Safety and Security Issues....................................458

C. Creating Uniformity Among Diversity .....................460

V. CONCLUSION: THE BENEFITS OF AN INTERNATIONAL PRISON OUTWEIGH THE RISKS....................................... 464

* Professor of Law, Texas A\&M University School of Law. A version of this article also appears in the Research Handbook on the International Penal System (Róisín Mulgrew \& Denis Abels, eds., 2016). 


\section{INTRODUCTION: MAKING THE CASE FOR AN INTERNATIONAL PRISON}

Where do individuals sentenced by an international criminal court go to serve their sentence? The answer is: "it depends." It depends on which international tribunal convicted the individual, which states have entered a cooperation agreement to enforce sentences with the particular tribunal, and which state the tribunal believes provides the best fit for that particular individual. ${ }^{1}$ Because there is currently no international prison or single location to enforce the criminal sentences imposed by international tribunals, ${ }^{2}$ where a convict serves their sentence is of constant uncertainty.

There have been many advancements in international criminal law within the past three decades, including the development of ad hoc tribunals to try those accused of war crimes or crimes against humanity. ${ }^{3}$ The ad hoc tribunals have

1. See Int'l Tribunal for the Prosecution of Persons Responsible for Serious Violations of Int'l Humanitarian Law Committed in the Territory of Former Yugoslavia Since 1991, Practice Direction on the Procedure for the International Tribunal's Designation of the State in Which a Convicted Person is to Serve His/Her Sentence of Imprisonment, ๆ 4-5, U.N. Doc. IT/137/Rev. 1 (Sept. 1, 2009) [hereinafter Yugoslavia Practice Direction] (giving the President of the Tribunal power to choose the State of a convict's imprisonment after participating countries inform the Tribunal of their willingness to take on the convict); Int'l Crim. Tribunal for Rwanda, Practice Direction on the Procedure for Designation of the State in Which a Convicted Person Is to Serve His/Her Sentence of Imprisonment, ๆ 2 -4 (Sept. 23, 2008) [hereinafter Rwanda Practice Direction] (giving the President of the Tribunal the power to choose the State of a convict's imprisonment after participating countries inform the Tribunal of their readiness and willingness to take on the convict); Special Court for Sierra Leone Office of the President, Practice Direction for Designation of State for Enforcement of Sentence, Iๆ 2-5 (July 10, 2009) [hereinafter Sierra Leone Practice Direction] (giving the President of the Tribunal power to choose the State of a convict's imprisonment after participating countries inform the Tribunal of their readiness and willingness to take on the convict).

2. See Barbora Holá \& Joris van Wijk, Life After Conviction at International Criminal Tribunals: An Empirical Overview, 12 J. INT'L CRIM. JusT. 109, 113 (2014) (explaining that tribunal prisoners are sent to states selected from a list of states willing to enforce the tribunals' prison sentences).

3. See S.C. Res. 827, ๆ 2 (May 25, 1993) (creating an international tribunal that has the sole purpose of prosecuting persons responsible for serious violations of international humanitarian law in the former Yugoslavia and adopting the Statute of the International Criminal Tribunal for the Former Yugoslavia); S.C. Res. 955, ๆ 1 (Nov. 8,1994 ) (adopting the Statute of the International Criminal Tribunal for Rwanda for the purpose of prosecuting persons responsible for violating international humanitarian law 
diminished immunity for some of the world's most heinous crimes, excluding terrorism and human trafficking. ${ }^{4}$ Ratification of the Rome Statute, which created the International Criminal Court ("ICC"), ${ }^{5}$ ensures a permanent approach to combating international crimes: individuals accused of war crimes and crimes against humanity will either be prosecuted in a court of law or ostracized and forced to live in hiding. ${ }^{6}$ This new era of accountability has resulted in the international prosecutions of high profile defendants and former heads of state. ${ }^{7}$ But, there

in Rwanda); S.C. Res. 1272, \& 1 (Oct. 25, 1999) (establishing a United Nations Transitional Administration in East Timor to deal with concerns regarding international humanitarian and human rights law violations); S.C. Res. 1315, ๆ 1-2 (Aug. 14, 2000) (recommending that the Secretary-General negotiate an agreement with the Sierra Leone government to create an independent special court to deal with violations of international humanitarian law).

4. See Rome Statute of the International Criminal Court, art. 5, July 17, 1998, 2187 U.N.T.S. 90 [hereinafter Rome Statute] (providing the International Criminal Court with jurisdiction over genocide, war crimes, crimes against humanity, and crimes of aggression). As noted in Article 5 of the Rome Statute, "The Court shall exercise jurisdiction over the crime of aggression once a provision is adopted in accordance with articles 121 and 123 defining the crime and setting out conditions under which the Court shall exercise jurisdiction with respect to this crime." Id.; see also Bureau of the Assembly of States Parties, Report of the Bureau on the Review Conference, था 15-22, U.N. Doc. ICC-ASP/8/43 (noting that the decision was made at the Rome Conference not to include terrorism or drug crimes within the jurisdiction of the International Criminal Court due to concerns that "the inclusion of drug crimes or the crime of terrorism would overburden the Court and detract from focusing its limited human and financial resources on the most serious crimes agreed to in 1998").

5. See Rome Statute, supra note 4, art. 1 (establishing the ICC, governed by the provisions of the statute, and granting it the power to exercise jurisdiction over persons for the most serious crimes of international concern); see also Mary Margaret Penrose, No Badges, No Bars: A Conspicuous Oversight in the Development of an International Criminal Court, 38 Tex. INT'L L.J. 621, 622 (2003) (asserting that the Rome Statute was the principal instrument creating the ICC).

6. See Richard Goldstone, The Role of the United Nations in the Prosecution of International War Criminals, 5 WASH. U.J.L. \& POL'Y 119, 121-24 (2001) (describing the need for a permanent international criminal court because establishing functional ad hoc tribunals takes considerable time, leaving war criminals free from prosecution until the wheels of justice can finally turn).

7. See Prosecutor v. Laurent Gbagbo, ICC-02/11-01/11, Decision on the Confirmation of Charges Against Laurent Gbagbo, ๆ $267-78$ (June 12, 2014) (noting the charges brought against former Ivory Coast President Laurent Gbagdo and the underlying facts giving rise to the charges); Prosecutor v. Slobodan Milosevic, Case No. IT-02-54-T, Amended Indictment "Bosnia and Herzegovina" (Int'l Crim. Trib. for the Former

Nov. 22 ,

2002) 
remain critical enforcement shortcomings in the current system. ${ }^{8}$ The ICC is literally just a court, a building with judges, lawyers, and staff, with no enforcement mechanisms to secure arrests or effectuate sentences. A mere eight states have entered sentencing enforcement agreements with the ICC, none within the past three years. ${ }^{9}$ This deficiency, while not currently posing an impediment to justice, will likely become a problem once the ICC moves beyond a handful of convictions. ${ }^{10}$

The Assembly of States Parties to the ICC specifically addressed the lack of cooperating states for sentence enforcement purposes at its Thirteenth Session in December 2014. ${ }^{11}$ The Bureau of Assembly of States issued a Report of the Bureau on Cooperation which highlighted the lack of enforcement agreements and the lack of recent commitment by States Parties to accept convicted individuals for enforcement purposes. ${ }^{12}$ The Report noted that the ICC has "stressed" that ad

http://www.icty.org/x/cases/slobodan_milosevic/ind/en/mil-ai040421-e.htm (indicting the former Serbian President for, inter alia, crimes against humanity and genocide).

8. See, e.g., Owen Bowcott, ICC Drops Murder and Rape Charges Against Kenyan President, GUARDIAN (Dec. 5, 2014, 9:10 AM), http://www.theguardian.com/world/2014/ dec/05/crimes-humanity-charges-kenya-president-dropped-uhuru-kenyatta (reporting that the charges against current Kenyan head of state, Kenyatta, were withdrawn because the Prosecutor could not secure sufficient evidence against Kenyatta due to obstruction and lack of cooperation from the Kenyan government).

9. Bureau of the Assembly of States Parties, Rep. of the Bureau on Cooperation, I 22, ICC-ASP/13/29 (Nov. 21, 2014).

10. See id. (noting the Court is concerned about having only eight States Parties participating in enforcement agreements because a range of geographical locations is needed in order to meet the cultural and linguistic needs of sentenced persons); see also InT'L CRIminal Court, Question \& Answer: The ICC APPEAls Chamber ConfiRms the Verdict AND the Sentence Against Thomas Lubanga Dyilo 2 (2014), http://www.icc-cpi.int/iccdocs/PIDS/publications/Lubanga-Q-a-A-Eng-01-12-2014.pdf (reporting that Lubanga Dyilo had served almost two-thirds of his fourteen year sentence in the Hague because there was still no determination as to where he would serve his sentence); David Davenport, International Criminal Court: 12 Years, \$1 Billion, 2 Convictions, ForBes (Mar. 12, 2014, 2:57 PM), http://www.forbes.com/sites/daviddavenport/2014/03/12/ international-criminal-court-12years-1-billion-2-convictions-2/ (reporting that the ICC has only convicted two individuals in its twelve year history).

11. Rep. of the Bureau on Cooperation, supra note 9, 920.

12. See id. I 22 (highlighting that the ICC has only signed eight sentence enforcement agreements and no further agreements have been reached since the most recent agreement was reached three years prior). 
hoc enforcement agreements, though permissible, "were not ideal." 13

Now that a permanent institution exists ready to prosecute those who are most deserving of international condemnation and punishment, it is strange that no corresponding permanent facility exists to house those convicted by the ICC. ${ }^{14}$ Remarkably, little attention has been given to the important realities of a permanent criminal court - prisoners facing lengthy prison terms. ${ }^{15}$ One cannot begin to comprehensively address international crime without addressing the full spectrum of prosecution, from arrest and pre-trial detention to incarceration, particularly when the primary penalty before international criminal tribunals remains imprisonment. ${ }^{16}$

We have an international criminal court, but no coexisting international prison. ${ }^{17}$ The maintenance of a permanent ICC requires us to assess the viability of a criminal justice system that fails to possess a centrally located, permanent prison

13. Id. ๆ 19.

14. See Penrose, supra note 5, at 621-22, 626, 642 (commenting that we must fix the shortcomings of the ICC, particularly the lack of a permanent facility to house ICC convicts); ICC Holds Groundbreaking Ceremony for Permanent Premises Construction, INT'L CRIMINAL COURT (Apr. 16, 2013), http://www.icc-cpi.int/en_menus/icc/about\% 20the\%20court/permanent\%20premises/latestnewsandcalendar/Pages/-ICC-holdsgroundbreaking-ceremony-for-Permanent-Premises-construction.aspx (lauding the construction of the ICC's permanent premises as a facility that should convey a strong image of an institution established to impart justice and combat impunity).

15. See Róisín Mulgrew, TOWARDS the DeVelopment of the International PENAL SYSTEM 56 (2013) (noting that international criminal tribunals have the authority to impose sentences and have final say on decisions relating to release, yet rely entirely on volunteer states to carry such sentences out); Penrose, supra note 5, at 626 (evaluating major deficiencies in the ICC, including the lack of a permanent facility to house ICC convicts); Mary Margaret Penrose, Spandau Revisited: The Question of Detention for International War Crimes, 16 N.Y.L. ScH. J. HuM. RTS. 553, 564, 580 (2000) (commenting on the problem of tribunals issuing sentences up to life in prison, which will outlast the temporary tribunals); Holá \& van Wijk, supra note 2, at 111-12 (comparing the length and severity of sentences at the ICTY, ICTR, and SCSL).

16. See Rome Statute, supra note 4, art. 77 (listing the applicable penalties, including imprisonment for a specified number of years - not to exceed thirty years and life imprisonment "when justified by the extreme gravity of the crime and the individual circumstances of the convicted person"); Penrose, supra note 5, at 642 (claiming that a world criminal court needs traditional components of a criminal justice system, such as police power and incarceration facilities, in order to be successful).

17. See Penrose, supra note 5, at 626. 
capable of housing convicted war criminals and those who committed crimes against humanity. ${ }^{18}$

Currently, all international tribunals rely on cooperating states to voluntarily agree to accept a particular convict. ${ }^{19}$ The list of willing states has been short and regionalized. The ICC, much like the enforcement system utilized by the ad hoc tribunals, continues to rely on cooperating states to help arrest those indicted and, eventually, house the convicted. ${ }^{20}$ The lack of enforcement mechanisms have plagued the various tribunals, as numerous individuals have avoided trial simply by evading arrest while others have served the majority of their sentence in a holding cell in the Netherlands. ${ }^{21}$ Because these states' cooperation is entirely voluntary, they can reject any individual presented. ${ }^{22}$ Thus, the ICC has no assurance that its convicts

18. See id. at 635-42 (asserting that the international community must address the need for the ICC to have a permanent prison facility if the Court is to be a success).

19. See, e.g., Yugoslavia Practice Direction, supra note 1, ๆ 2 \& 4 (directing the Registrar of the International Tribunal to report to the Tribunal's President the Member State's willingness to accept a convicted person). The U.N. Security Council established the International Residual Mechanism for Criminal Tribunals to conclude the remaining tasks, including the enforcement of sentences facing the now dormant ICTY and ICTR. S.C. Res. 1966, arts. 2 \& 25(2) (Dec. 22, 2010). The MICT began functions relating to the ICTR on July 1, 2012 and the ICTY on July 1, 2013. Id. pmbl. I 1. Article 25 addresses the "Enforcement of Sentences," and Article 26 addresses "Pardon or Commutation of Sentences." Id. arts. $25 \& 26$. Article 25 of the MICT provides that "[i]mprisonment shall be served in a State designated by the Mechanism from a list of states with which the United Nations has agreements for this purpose. Such imprisonment shall be in accordance with the applicable law of the State concerned, subject to the supervision of the Mechanism.” Id. art. 25.

20. See Rome Statute, supra note 4, art. 103(1)(a) ("A sentence of imprisonment shall be served in a State designated by the Court from a list of States which have indicated to the Court their willingness to accepted sentenced persons.").

21. See Klaus Hoffmann, Some Remarks on the Enforcement of International Sentences in Light of the Galić Case at the ICTY, 10 ZEITSCHRIFT FÜR INTERNATIONALE STRAFRECHTSDOGMATIK 838, 842 (2011) (Ger.) ("Already today, many perpetrators spent a number of years during pre-trial and trial stages in the UN prison in Scheveningen/The Hague. In case of very short prison sentences, some convicted prisoners have never been transferred to another state of enforcement.").

22. See Rome Statute, supra note 4, art. 103(1)(b)-(c) (stating that a State shall inform the Court whether it will accept a convict, and providing that a State may attach conditions to its willingness to accept sentenced persons). Holá \& van Wijk, supra note 2, at 115 noted that there is a "double-consent" process for designating a state for sentence enforcement, by which "first, a state must enter into an enforcement agreement with a 
will have an available state to enforce its penalties once an individual is convicted and sentenced. ${ }^{23}$

It seems unlikely that a twenty-first century international criminal justice system can successfully exist on a one-dimensional level - the maintenance of a court without corresponding police and prison enforcement mechanisms. ${ }^{24}$ The current model is woefully incomplete, embracing the paradigm of the past, not the modern world. ${ }^{25}$ We have abandoned the ad hoc tribunal approach, recognizing its shortcomings. We have embraced the need for a permanent international criminal justice system. ${ }^{26}$ Why then, do we continue to use an ad hoc, cooperating states model to mete out penalties imposed by a permanent criminal court? ${ }^{27}$ Historical deficiencies suggest the time is ripe to consider whether an international prison system is a necessary component of the nascent ICC system. ${ }^{28}$

This Article asserts that a permanent international prison is a necessary, if not indispensable, component of any effective international criminal justice system. It begins by first

tribunal and express its willingness to enforce sentences in [the] future and second, these states agree to accept the individual convicts on an ad hoc basis."

23. See Rome Statute, supra note 4, art. 103(4) ("If no State is designated ... the sentence of imprisonment shall be served in a prison facility made available by the host State.").

24. See Penrose, supra note 5, at 625-26 (arguing that because the ICC lacks a coercive enforcement mechanism and permanent prison system, the Court is destined for limited success).

25. See id. at 642 (arguing that by maintaining the inadequate enforcement and imprisonment mechanisms that plagued the ICTY and ICTR, the ICC is not sufficiently capable of enforcing international criminal law).

26. See generally Duane W. Krohnke, International Criminal Justice: Winding down Two Ad-Hoc Criminal Tribunals, DWKCOMMENTARIES (June 18, 2011), http:// dwkcommentaries.com/2011/06/18/international-criminal-justice-winding-down-two-adhoc-criminal-tribunals/ (discussing the phasing out of the ICTY and ICTR and how the ICC solves some of those tribunals' shortcomings).

27. See, e.g., Penrose, supra note 5, at 642 (arguing that the ICC should implement the "traditional components of a criminal justice system" to avoid dependence on the political influences of the participating states).

28. See Róisín Mulgrew, On the Enforcement of Sentences Imposed by International Courts: Challenges Faced by the Special Court for Sierra Leone, 7 J. INT'L CRIM. JUST. 373, 395-96 (2009) (noting that a lack of support from participating states has made SCSL enforcement difficult and that the creation of an international prison system needs to be considered). 
addressing the historical approach to international sentencing. Next, it discusses the inadequacies of the status quo. Finally, it argues the time has come to construct a permanent international prison, rather than adhere to the ad hoc approach in dealing with international criminals and convicts.

\section{THE HISTORICAL APPROACH TO INTERNATIONAL SENTENCING: FROM NUREMBERG TO THE COOPERATING STATES MODEL}

Following the United Nations' creation of the International Criminal Tribunal for Yugoslavia (ICTY) ${ }^{29}$ and, shortly thereafter, the International Criminal Tribunal for Rwanda (ICTR), ${ }^{30}$ the international community convicted its first international war criminals since the Nuremberg Trials and the Tokyo Tribunal following World War II. ${ }^{31}$ But, unlike the World War II courts that relied upon the Allied occupation to carry out the penalties, including imprisonment and executions, the modern international system has no single entity tasked with overseeing the enforcement of prison sentences. ${ }^{32}$ While the victorious Allies were able to utilize existing prison facilities in Germany and Japan, the ICTY and ICTR had no such luxury. ${ }^{33}$ Instead, the ICTY and ICTR were forced to rely on cooperating states to aid in the enforcement of these court's criminal sentences, all of which are strictly limited to terms of imprisonment. ${ }^{34}$

29. See S.C. Res. 827, supra note 3, If 2 (creating the International Criminal Tribunal for Yugoslavia).

30. See S.C. Res. 955, supra note 3, of 1 (creating the International Criminal Tribunal for Rwanda).

31. See generally About the ICTY, Int'l Crim. Trib. for the Former Yugoslavia, http://www.icty.org/en/about (last visited Mar. 29, 2016) (showing that the ICTY and ICTR were the first criminal tribunals to be established since the criminal tribunals in Nuremberg and Japan).

32. See Penrose, supra note 15 , at 565-66 (detailing that the sentences handed down during the Nuremberg Trials were overseen by the Allies, while the enforcement of ICTY and ICTR sentences are governed by both the tribunal and the host state).

33. See id.

34. See S.C. Res. 827, supra note 3, art. 27 (stating that imprisonment shall be served in a cooperating state, and that "imprisonment shall be in accordance with the applicable law of the State concerned, subject to the supervision of the International 
Likewise, while the Special Court for Sierra Leone (SCSL) contains a statutory preference for enforcing sentences within Sierra Leone, ${ }^{35}$ the realities of the situation in a povertystricken, post-conflict nation state has precluded this from occurring. ${ }^{36}$ So, the SCSL, much like the ICTY and ICTR, "cannot directly implement its own sanctions" due solely to the lack of a functioning prison facility. ${ }^{37}$ As a result, all SCSL convicts have been placed outside Sierra Leone to serve out their respective sentences..$^{38}$

In contrast to the modern ad hoc tribunals, the early international tribunals at Nuremberg and Tokyo provided centralized prison space to enforce the international criminal sentences imposed. ${ }^{39}$ Following the World War II tribunals, that space remained in the conquered territories of Germany and Japan. ${ }^{40}$ Modernly, however, the ICC, much like the ICTY and

Tribunal"); S.C. Res. 955, supra note 3, art. 26 (limiting place of imprisonment to "any of the States on a list of States which have indicated to the Security Council their willingness to accept convicted persons").

35. Agreement Between the United Nations and the Government of Sierra Leone on the Establishment of a Residual Special Court for Sierra Leone, Statute of the Residual Special Court for Sierra Leone, art. 23(1) (2010), http://www.rscsl.org/Documents/ RSCSL\%20Agreement\%20and\%20Statute.pdf [hereinafter RSCSL Statute]; Mulgrew, supra note 28, at 374

36. Mulgrew, supra note 28, at 374 .

37. Id.

38. See id. (stating that SCSL has to rely on third-party states to accept custody of SCSL prisoners); Rwanda Signs Prisoner Deal with Sierra Leone Court, ICC OBSERVERS (Mar. 21, 2009), http://iccobservers.wordpress.com/tag/special-court-for-sierra-leone/ (noting that SCSL convicts are being sent to Mpanga Prison in Rwanda); Distance from Uganda to Sierra Leone, DisTANCEFromTo (last visited Oct. 28, 2015), http://distancefromto.net/distance-from/Uganda/to/Sierra+Leone (showing that Uganda, where Mpanga prison is located, is 3,070 miles from Sierra Leone); Liberian Charles Taylor Moved to British Prison to Serve War Crimes Conviction, TELEGRAPH (Oct. 15, 2013, 2:43 PM), http://www.telegraph.co.uk/news/worldnews/africaandindianocean/ liberia/ 10380401/Liberian-Charles-Taylor-moved-to-British-prison-to-serve-war-crimesconviction.html (detailing that the lone exception to sending its prisoners to Mpanga is Charles Taylor, who was sent to the United Kingdom to serve his sentence).

39. See Penrose, supra note 15, at 564-65 (stating that unlike the current tribunals, convicts from the Nuremberg and Tokyo served their entire sentences at their respective facilities).

40. See SPANDAU, ENCYC. BRITANNICA, http://www.britannica.com/place/Spandau\# ref980279 (last visited Oct. 17, 2015) (detailing that the Spandau prison located near Berlin housed the Nazi War Criminals until the last one died in 1987); The Tribunal - 
ICTR before it, does not possess an occupied territory and must defer to the willingness of other cooperating states to effectuate its sentences. ${ }^{41}$ This decentralized approach to imprisonment has implications beyond mere location of prison space. The absence of a cohesive international prison system raises complications relating to family access, language difficulties, and rehabilitation, thereby potentially undermining the ultimate efficacy of international justice.

While the ICTY and ICTR initially prohibited imprisonment in either Yugoslavia or Rwanda, a domestic solution was successfully used during World War II due to the occupying nations controlling the prison facilities. This local approach has been incorporated into one modern international tribunal. ${ }^{42}$ The Extraordinary Chambers in the Courts of Cambodia ("ECCC"), a United Nations-backed domestic court tasked with investigating and prosecuting crimes relating to the Khmer Rouge regime of the 1970s, has adopted a domestic sentencing approach for its convicts. ${ }^{43}$ Much like the World War II tribunals, the ECCC will

An Overview, TOKYO WAR CRIMES TRIAL - A Digital Exhibition, http://lib.law.virginia.edu/ imtfe/tribunal (last visited Oct. 28, 2015) (stating that all the war criminals in the Military Tribunal were sent to and died in Sugamo Prison in Tokyo).

41. See supra notes $20 \& 34$ and accompanying text.

42. See Kaing Guek Eav Transferred to Kandal Prison, EXTRAORDINARY CHAMBERS IN THE COURTS OF CAMBODIA (June 18, 2013, 2:33 PM), http://www.eccc.gov.kh/en/articles/ kaing-guek-eav-transferred-kandal-prision (detailing that the ECCC is a domestic legal system in which Cambodian authorities are responsible for the imprisonment of those individuals convicted by the ECCC); Penrose, supra note 15 (showing that the Nuremberg Tribunal had the Allies oversee the enforcement of their sentences while the Tokyo Tribunal had the U.S. Army oversee the enforcement of their sentences).

43. See About ECCC, Extraordinary Chambers in the Courts of Cambodia (last visited Oct. 17, 2015), http://www.eccc.gov.kh/en/about-eccc. The ECCC was created by Cambodian law to address crimes committed during the Khmer Rouge regime between the years 1975-1979. Id. "The government of Cambodia insisted that, for the sake of the Cambodian people, the trial must be held in Cambodia using Cambodian staff and judges together with foreign personnel." Id. Still, the ECCC utilizes a cooperative approach between national law and the United Nations. Id. See generally Agreement Between the United Nations and the Royal Government of Cambodia Concerning the Prosecution Under Cambodian Law of Crimes Committed During the Period of Democratic Kampuchea, U.N.-Cambodia, June 6, 2003, 2329 U.N.T.S. 117. 
place its inmates directly in domestic prisons, ${ }^{44}$ which will provide far easier transitions relating to language, religion, access to counsel and visitation issues. To date, only one person, Kaing Guek Eav, has been found guilty, sentenced by the ECCC, and transferred to Kandal Provincial Prison in Cambodia. ${ }^{45}$ Thus, there is little evidence of how the domestic model performs in modern society. ${ }^{46}$ But, if past experiences with Spandau prison in Berlin, Germany ${ }^{47}$ and Sugamo prison in Tokyo $^{48}$ are any indication, the domestic model at least offers the

44. See Kaing Guek Eav Transferred to Kandal Prison, supra note 42 (detailing that the ECCC is a domestic legal system in which Cambodian authorities are responsible for the imprisonment of those individuals convicted by the ECCC).

45. Id.; see also Prosecutor v. Kaing Guek Eav alias Duch, Case No. 001, Appeal Judgment, pt. VIII, at 320 (Extraordinary Chambers in the Courts of Cambodia July 26, 2010), http://www.eccc.gov.kh/sites/default/files/documents/courtdoc/Case\% 20001Appeal JudgementEn.pdf (upholding convictions for crimes against humanity and war crimes but overturning the sentence of thirty-five years and replacing it with life imprisonment). Two others, Nuon Chea and Khieu Samphan, have been found guilty and received life sentences; they are currently in a detention center waiting for their appeals to be heard. Prosecutor v. Nuon Chea \& Khieu Samphan, Case No. 002/01, Judgement, I 20 (Extraordinary Chambers in the Courts of Cambodia Aug. 7, 2014), http://www.eccc.gov.kh/sites/default/files/documents/courtdoc/2014-08-07\%2017:04/E313_ Trial\%20Chamber\%20Judgement\%20Case\%20002_01_ENG.pdf; Chris Blake \& Kevin Doyle, Khmer Rouge Leaders Sentenced to Life in Jail for War Crimes, BloOMBERG (Aug. 7, 2014, 1:18 AM), http://www.bloomberg.com/news/articles/2014-08-07/khmerrouge-leaders-sentenced-to-life-in-prison-for-war-crimes.

46. See International Criminal Tribunals and Special Courts, GLoB. Policy FORUM (last visited Oct. 28, 2015), http://globalpolicy.org/internationaljustice/international-criminal-tribunals-and-special-courts.html (listing the Special Courts in Sierra Leone, Lebanon, Cambodia, and East Timor as the only international criminal tribunals to develop after those in Rwanda and Yugoslavia); see also Nuon Chea and Khieu Samphan Sentenced to Life Imprisonment for Crimes Against Humanity, Extraordinary Chambers in the Courts of Cambodia (Aug. 7, 2014), http://www.eccc.gov.kh/en/articles/nuon-chea-and-khieu-samphan-sentenced-life-

imprisonment-crimes-against-humanity (detailing that two additional defendants, Nuon Chea and Khieu Samphan have both been convicted of crimes against humanity and have been sentenced by the ECCC Trial Chamber to life in prison); Lauren Crothers, Khmer Rouge Leaders Appeal Life Sentences for Crimes Against Humanity, GUARDIAN (Sept. 30, 2014, 4:40 AM), http://www.theguardian.com/ world/2014/sep/30/khmer-rougeleaders-appeal-life-sentences-crimes-humanity (stating that Chea and Samphan filed a notice of appeal).

47. SPANDAU, supra note 40

48. Bill Barrette, ART AND Exchange at Sugamo PRISON, 1945-52, JAPAN Pol'y RES. INST. OCCASIONAL PAPER NO. 33 (Oct. 2004), http://www.jpri.org/publications/ occasionalpapers/op33.html. 
benefits of a common language, a common culture, and better access to family.

Perhaps recognizing the inherent limitations of a pure cooperating states model, the ICC has adopted a hybrid approach that relies primarily on willing states to house its convicts but also provides that in a given case, where no such nation state provides its acquiescence, the ICC Host State, the Netherlands, will accommodate the convict in a domestic prison. ${ }^{49}$ The ICC's statutory design accepts there may be instances where it is impossible to secure a cooperating state placement. The creation of this safety net implicitly acknowledges that the cooperating state model offers an incomplete solution, at best, and provides further evidence that a new, more permanent system should be achieved. The lack of state cooperation was further addressed at the ICC when the Review Conference recently added the option that "imprisonment may be served in a prison facility made available in the designated State through an international or regional organization, mechanism or agency." 50

What remains surprising, in light of the lack of state cooperation spanning from the ad hoc tribunals to the ICC, is that the international community has not pressed the need for an alternative to the status quo. It has made no discernable movement toward a permanent international prison. The primary shortcoming of the cooperating states model is that only a small number of nation states participate, which results in a sparse, regionalized approach to incarceration. ${ }^{51}$ Few nation

49. See Rome Statute, supra note 4, art. 103(4) (stating that "if no State is designated [for enforcement of the sentence], the sentence of imprisonment shall be served in a prison facility made available by the host State"); id. art. 3(1) (establishing the Netherlands as "the host State").

50. Review Conference of the Rome Statute of the International Criminal Court, ICC Res. RC/Res.3, I 2 (June 8, 2010) (noting the ICC's mindfulness "of the need for broader participation of States in the enforcement of sentences in order to allow for such enforcement in all relevant regions and sub regions").

51. See Rep. of the Bureau on Cooperation, supra note 9, If 22 (stating that the Bureau only has eight States that have signed sentence enforcement agreements); Mulgrew, supra note 28, at 395 (observing that "with many of the difficulties relating to enforcement being attributable to the lack of support from states, it is perhaps time for international courts to take direct control over the implementation of their sanctions"). 
states have expressed willingness to receive international convicts from these international tribunals, with most accepting countries being regionally concentrated in Europe and Africa. ${ }^{52}$ The continents of Asia, Australia, and the Americas (with the exception of Colombia) have, thus far, failed to contribute prison space or facilities to enforce internationally imposed sentences. ${ }^{53}$ Russia, too, has withheld its cooperation from the international tribunals, though several Eastern European countries have entered enforcement agreements. ${ }^{54}$ Simply put, the majority of the world's governments and population have decided not to cooperate. ${ }^{55}$

Thus, part of the ICC's efficacy, assuming that prosecutions and sentences become more common, will depend on whether there are sufficient nation states willing to house, service, and rehabilitate convicted individuals. ${ }^{56}$ Currently, there have only

52. See Holá \& van Wijk, supra note 2, at 113 (noting that fifty-seven persons convicted by the ICTY, ICTR, or SCSL are serving their sentences "in various European and African countries").

53. Cf. Bilateral Agreements, INT'L CRIM. TRIB. FOR RWANDA, http://unictr.unmict. org/en/documents/bilateral-agreements (last visited Mar. 29, 2016) (showing that only eight countries entered bilateral agreements with the ICTR to enforce sentences: Mali (1999), Benin (1999), Swaziland (2000), France (2004), Italy (2004), Sweden (2004), Rwanda (2008), and Senegal (2010)); Member States Cooperation, INT'L CRIM. TRIB. FOR FORMER YUGOSLAVIA, http://www.icty.org/en/documents/member-states-cooperation (last visited Mar. 29, 2016) (listing the sixteen countries that have entered into bilateral agreements to enforce ICTY sentences).

54. See Member States Cooperation, supra note 53. Sixteen countries, including Eastern European countries, have entered bilateral agreements with the ICTY to enforce sentences, but Russia has not. $I d$. The countries that have entered bilateral agreements with the ICTY include: Italy (1997), Finland (1997), Norway (1998), Austria (1999), Sweden (1999), France (2000), Spain (2000), Denmark (2002), United Kingdom (2004), Belgium (2007), Ukraine (2007), Portugal (2007), Estonia (2008), Slovakia (2008), Poland (2008), and Albania (2008). Id.

55. See supra notes $20-22 \& 53$ and accompanying text.

56. See Mulgrew, supra note 28, at 378 (explaining that states must be willing to house international convicts). A criticism - not without force - is that the work of the ICC has been slow and costly. See Davenport, supra note 10 (explaining the ICC's low conviction rate and high operation cost). The ICC has been in existence for twelve years, has received approximately $\$ 1$ billion in operating costs, and has two convictions to date. $I d$. This pace does not fortify the call for any prison, much less an international prison. See id. (stating the ICC is too expensive to justify). Rather, as David Davenport argues, this funding "would be better utilized to strengthen national and regional criminal justice" systems. Id. 
been two final convictions before the ICC. ${ }^{57}$ Both sentences are being enforced by their domestic country, the Democratic Republic of the Congo, through ad hoc agreements rather than in any "cooperating state" with a prior ICC sentencing agreement. ${ }^{58}$

The ICC constricts a cooperating state's power to reduce sentences until "the person has served two thirds of the sentence, or twenty five years in the case of life imprisonment." 59 Similarly, the Mechanism for International Criminal Tribunals ("MICT") now uses a "rule of thumb" that convicts are eligible for early release once they have served two-thirds of their sentence. ${ }^{60}$ But, even with the "two-thirds" approach, the governing laws of a particular cooperating state may be at odds with ICC and MICT practices. A far more predictable and certain approach would be to create a truly international prison system, so that decisions relating to release and rehabilitation are standardized for all international convicts through policies

57. Davenport, supra note 10. The conviction of Thomas Lubanga Dyilo became final when the Appeals Chamber confirmed the verdict and fourteen-year sentence on December 1, 2014. Prosecutor v. Thomas Lubanga Dyilo, ICC-01/04-01/06, Judgment on the Appeal of Mr. Thomas Lubanga Dyilo Against his Conviction, I 529 (Dec. 1, 2014). The other conviction involves Congolese militia leader Germain Katanga, who was sentenced to twelve years' imprisonment by Trial Chamber II on May 23, 2014. Prosecutor v. Germain Katanga, ICC-01/04-01/07, Decision on Sentence Pursuant to Article 76 of the Statute, 1170 (May 23, 2014).

58. Both men have been transferred to the Democratic Republic of the Congo to serve their twelve- and fourteen-year sentences. Prosecutor v. Germain Katanga, ICC-01/04-01/07, Ad Hoc Agreement Between the Government of the Democratic Republic of the Congo and the International Criminal Court on Enforcement of the Sentence of the International Criminal Court Imposed on Mr. Germain Katanga (Nov. 24, 2015), https://www.icc-cpi.int/iccdocs/doc/doc2179227.pdf; Prosecutor v. Thomas Lubanga Dyilo, ICC-01/04-01/06, Ad Hoc Agreement Between the Government of the Democratic Republic of the Congo and the International Criminal Court on Enforcement of the Sentence of the International Criminal Court Imposed on Mr. Thomas Lubanga Dyilo (Nov. 24, 2015), https://www.icc-cpi.int/iccdocs/doc/doc2179222.pdf; see also Press Release, Int'l Crim. Ct., Thomas Lubanga Dyilo and Germain Katanga Transferred to the DRC to Serve their Sentences of Imprisonment, ICC Press Release PR1181 (Dec. 19, 2015), https://www.icc-cpi.int/en_menus/icc/press\%20and\%20media/press\%20releases/ Pages/pr1181.aspx.

59. Rome Statute, supra note 4, art. 110.

60. See Jonathan H. Choi, Early Release in International Criminal Law, 123 YALE L.J. 1784, 1788 (2013) (noting convicts presumptively only need to serve two-thirds of their sentence to be eligible for early release). 
created and enforced by an international prison. ${ }^{61}$ While the ICC and MICT remain the final word on release issues, having a single international entity (particularly one with international prisoner expertise) provide recommendations on release would be an improvement over the status quo. ${ }^{62}$

In over a decade of existence, with only two final convictions, the ICC has little current need for actual prison space. But, the permanence of the ICC, coupled with its ongoing investigations and prosecutions, suggests that more convictions will occur in the future. ${ }^{63}$ Because war crimes and crimes against humanity tend to be carried out by large groups of people, a given conflict can produce several defendants. If this remains true, a present or future conflict could produce an abrupt uptake in convictions. If the ICC hits a critical mass of sentenced individuals, will there be a sufficient number of countries willing to accept and bear the cost of housing ICC convicts? The resolution of this question, coupled with the shortcomings in the status quo, strengthen the case for the creation of a truly international prison.

\section{ShoRTCOMINGS IN THE StATUs QUO}

\section{A. The Lack of Cooperating States}

The ICTY, ${ }^{64}$ ICTR, ${ }^{65}$ and SCSL ${ }^{66}$ have ceased their official business, turning over all future activity to the $\mathrm{MICT}^{67}$ or, in the

61. See, e.g., Rome Statute, supra note 4, arts. 59(4), 60(2), 81(3)(b)-(c) (outlining the discretionary powers the ICC grants to courts to decide certain questions of release of prisoners in limited circumstances).

62. See id.

63. See supra note 57 and accompanying text (listing the ICC's various ongoing cases). Currently, the ICC reports it has twenty three ongoing cases. Id. In addition, the ICC is investigating nine distinct situations that could yield numerous defendants. $I d$. From Uganda to the recent investigation opened involving Israel's treatment of the Palestinians, there is an understanding that the ICC's judicial footprint will grow in the coming years. $I d$.

64. See S.C. Res. 1966, supra note 19, I 1 (establishing that the International Mechanism for Criminal Tribunals would begin functioning for the ICTY on July 1, 2013).

65. See id. (indicating the MICT began functioning for the ICTR on July 1, 2012). 
case of the SCSL, the Residual Special Court for Sierra Leone ("RSCSL"). ${ }^{68}$ All outstanding business, including potential future trials which would have fallen within the jurisdiction of the ad hoc tribunals, has been transferred to the MICT ${ }^{69}$ and RSCSL. ${ }^{70}$ The most important remaining business continues to be oversight of the criminal sentences imposed by each of these ad hoc tribunals, including questions of early release. ${ }^{71}$ Accordingly, the United Nations Security Council granted power to the MICT and RSCSL to oversee the remaining functions of the ad hoc tribunals after their respective mandates expired. ${ }^{72}$ This obligation includes designating potential enforcement states and determining questions of pardon and early release. ${ }^{73}$ The MICT and RSCSL, just as the ICTY and ICTR before them, maintain Practice Directions to help guide these early release decisions. ${ }^{74}$ In contrast to the ad hoc tribunals, the RSCSL has

66. The SCSL closed in 2013 and was replaced by the Residual Special Court for Sierra Leone (RSCSL). Agreement Between the United Nations and the Government of Sierra Leone on the Establishment of a Residual Special Court for Sierra Leone, art. 1 (2010) [hereinafter Agreement to Establish RSCSL]; The Mandate of the Residual Special Court for Sierra Leone: Background, SPECIAL COURT FOR SiERRA LEONE, RESIDUAL SPECIAL COURT FOR SIERRA LEONE, http://www.rscsl.org/RSCSLMandate.html (last visited Mar. 30, 2016).

67. Security Council Establishes Residual Mechanism to Conclude Tasks of International Criminal Tribunals for Rwanda, Former Yugoslavia, UnITED NATIONS (Dec. 22, 2010), http://www.un.org/press/en/2010/sc10141.doc.htm [hereinafter Security Council Establishes Residual Mechanism].

68. The Mandate of the Residual Special Court for Sierra Leone: Background, supra note 66 .

69. See About the MICT, U.N. Mechanism FOR INT'L CRIM. TRIBS., http://www. unmict.org/en/about (last visited Oct. 9, 2015) ("Securing the arrest, transfer and prosecution of the nine remaining fugitives still wanted for trial by the ICTR is a top priority for the Mechanism.”).

70. The Mandate of the Residual Special Court for Sierra Leone: Background, supra note 66.

71. See id. (stating that the authority of RSCSL to manage requests for review of convictions and acquittals may extend until 2055).

72. Security Council Establishes Residual Mechanism, supra note 67. The MICT was initially put into place for a period of four years with a review scheduled every two years thereafter. $I d$.

73. S.C. Res. 1966, supra note 19, arts. 25-26; RSCSL Statute, supra note 35 , arts. 23-24.

74. See generally Mechanism for Int'l Crim. Tribs., Practice Direction on the Procedure for Designation of the State in Which a Convicted Person Is to Serve His or Her 
noted in its Practice Direction that inmates are not eligible for early release prior to serving two-thirds of their sentence. ${ }^{75}$ And, while the MICT Practice Direction suggests that domestic law in the enforcing state triggers eligibility for early release, ${ }^{76}$ one source notes the MICT has adopted the two thirds rule as an informal governing principle. ${ }^{77}$

As of November 19, 2014, the MICT was overseeing the enforcement of 18 sentences on behalf of the ICTY, with inmates spread over twelve countries, and twenty nine sentences on behalf of the ICTR split between only two African countries. ${ }^{78}$ The MICT reported that sixteen ICTR convicts were serving their sentences in Mali, and thirteen more were in Benin. ${ }^{79}$ In contrast, the eighteen ICTY convicts were all serving their sentences in European states including "Austria (1), Belgium

Sentence of Imprisonment, I 1, MICT/2 Rev. 1 (Apr. 24, 2014) [hereinafter MICT Practice Direction, Designation of State] (establishing an internal procedure for MICT's "designation of the State in which a convicted person is to serve his or her sentence of imprisonment"); Mechanism for Int'l Crim. Tribs., Practice Direction on the Procedure for the Determination of Applications for Pardon, Commutation of Sentence, and Early Release of Persons Convicted by the ICTR, the ICTY or the Mechanism, ๆ 1, MICT/3 (July 5, 2012) [hereinafter MICT Practice Direction, Early Release] (establishing an internal procedure for MICT's "determination of applications for pardon, commutation of sentence, and early release of persons convicted by the respective Tribunal or by the Mechanism"); Special Court for Sierra Leone, Practice Direction on the Conditional Early Release of Persons Convicted by the Special Court for Sierra Leone, I 2 (Jan. 10, 2013) [hereinafter SCSL Practice Direction, Early Release] (providing criteria in determining a convicted person's eligibility for conditional early release).

75. SCSL Practice Direction, Early Release, supra note 74, ๆ 2(A).

76. The Practice Direction section on "Notification of Eligibility" indicates that "[u]pon the convicted person becoming eligible for pardon, commutation of sentence or early release under the law of the State in which the convicted person is serving his or her sentence (the "enforcing State"), the enforcing State shall... notify the Mechanism accordingly." MICT Practice Direction, Early Release, supra note 74, If 2 (emphasis added). See also S.C. Res. 1966, supra note 19, art. 26 ("If, pursuant to the applicable law of the State in which the person convicted by the ICTY, the ICTR, or the Mechanism is imprisoned, he or she is eligible for pardon or commutation of sentence, the State concerned shall notify the Mechanism accordingly." (emphasis added)).

77. See supra note 60 and accompanying text.

78. Assessment and Progress Rep. of the President of the Int'l Residual Mechanism for Crim. Tribs. (2014), Judge Theodor Meron, for the Period From 16 May to 19 November 2014, transmitted by Letter Dated 19 November 2014 from the President of the Int'l Residual Mechanism for Crim. Tribs. Addressed to the President of the Sec. Council, ๆๆ 43-44, U.N. Doc. S/2014/826 (Nov. 19, 2014).

79. Id. 43. 
(1), Denmark (2), Estonia (3), Finland (1), France (1), Germany (3), Italy (1), Norway (1), Poland (1), Portugal (1) and Sweden (2)." 80 Six ICTR convicts and two ICTY convicts are still being housed at the detention units in Arusha and the Hague, respectively. ${ }^{81}$ All existing bilateral agreements entered into by the ad hoc tribunals continue in force for the MICT. ${ }^{82}$

The MICT, like each international tribunal preceding it, continues - somewhat in vain - to call on the cooperation of states to help secure additional agreements for the enforcement of sentences. ${ }^{83}$ No new state that had not previously provided prison space for the enforcement of sentences to either the ICTY or ICTR has entered into a bilateral agreement with the MICT. ${ }^{84}$ This inertia underscores the need for change, permanent change.

The lack of participating states under the cooperating states model continues to be a problem. ${ }^{85}$ Every ad hoc court, the MICT, and now the ICC continue to call on states to aid in the enforcement of sentences, generally to little avail. ${ }^{86}$ If states refuse to step up and accept these international prisoners, the system of international criminal justice will face a serious threat to its future endeavors. In the Bureau of the Assembly of States Parties Report of the Bureau on Cooperation, the Bureau exposed the second main shortcoming to the existing model: a lack of sufficient diversity to accommodate the sentencing enforcement needs. The Report asserts:

\section{Id. ๆ 44 .}

81. Id. ๆๆ 43-44.

82. See id. If 41 ("The agreements concluded by the United Nations for the two Tribunals remain in force for the Mechanism.”).

83. See id. ("The Mechanism relies on the cooperation of States for the enforcement of sentences.").

84. See Member State Agreements, U.N. Mechanism InT'L CRIM. TRIBS., http://www. unmict.org/en/basic-documents (last visited Mar. 31, 2016) (demonstrating that only the pre-existing enforcement agreements with the ICTY and ICTR remain in effect - no new member state agreements are reported).

85. Rep. of the Bureau on Cooperation, supra note 9, ๆ 22.

86. Id.; Int'l Residual Mechanism for Crim. Tribs., Second Annual Rep., ๆ 66, U.N. Doc. A/69/226-S/2014/555 (Aug. 1, 2014) ("The Mechanism actively sought the cooperation of existing enforcement States in enforcing the sentences of the two Tribunals and continued efforts to negotiate additional agreements with States in order to increase its enforcement capacity."). 
The Court would wish to have a broad range of agreements in different geographical areas and different normative regimes, so as to be ready to determine enforcements. This would allow the Court to meet the cultural and linguistic needs for sentenced persons, including for the families of the individuals concerned. ${ }^{87}$

The continuing business of the ad hoc tribunals consumes scarce incarceration resources. ${ }^{88}$ Amnesty International specifically noted, prior to the Thirteenth Annual Meeting of States Parties to the Rome Statute in December 2014, that the need to secure cooperating states for the enforcement of sentences remains acute. ${ }^{89}$ In fact, Amnesty echoed the concern first reported by the Bureau that only eight states have thus far entered enforcement agreements, with no new state entering into such an agreement in the past three years. ${ }^{90}$ This dearth of cooperation has existed for each of the modern international tribunals, from the ad hoc tribunals to the ICC. Simply put, the cooperating states model has proven a constant struggle.

\section{B. Conditions, Distance, Language, Security and Cultural Distinctions}

A second shortcoming in the cooperating states model is the reality that the prisons made available by the few cooperating states vary dramatically from inmate to inmate. ${ }^{91}$ The conditions, rehabilitation opportunities, and other penal issues

87. Rep. of the Bureau on Cooperation, supra note 9, $₫ 22$.

88. See, e.g., Mulgrew, supra note 28, at 374 ("Despite the statutory preference for enforcement of SCSL sentences in Sierra Leone, the host state is not in a position to accept custody of SCSL prisoners[,]" but rather must "rely on third states for the implementation of its sentences."); Hoffmann, supra note 21, at 841-42 (raising the question "whether it would not be preferable to establish a truly international prison with a set of international rules for imprisonment").

89. AMnesty InT'L, InTERnATIONAL CRIMINAL COURT 3 (2014), https://www. amnesty.org/download/Documents/8000/ior530102014en.pdf.

90. $I d$.

91. See Holá \& van Wijk, supra note 2, at 118-19 (illustrating that because "the law of the tribunals is virtually silent regarding the type of prisons international convicts shall be sent to," the determination lies "with domestic authorities and arguably differs by state, but also by convict”). 
are matters largely left to the discretion of individual states. ${ }^{92}$ As Professors Holá and van Wijk observe:

Whether an international prisoner is placed in a high security prison, protective custody, regular prison, or for example, an open prison, has a [sic] great consequences for his daily life and influences the execution of his/her sentence to a considerable extent. The law of the tribunals is virtually silent regarding the type of prisons international convicts shall be sent to. ${ }^{93}$

The governing statutes merely mandate conformance with basic international standards. ${ }^{94}$ But, most germane issues are resolved locally and can vary quite dramatically from country to country and even prison to prison. ${ }^{95}$

One would expect that the international community would strive to provide similar imprisonment conditions to those convicted of the same crime or even in the same conflict. However, the status quo depends fully on the cooperation of states that are free to receive only certain individuals and, thereafter, can place the individual in varying types of custody, which need only satisfy basic international norms. Such deviations are problematic and result in some inmates' sentences carrying harsher conditions than others. Two ICTY convicts might receive the exact same sentence of fifteen years. But, depending on the prison conditions they face, their experiences may be markedly different. ${ }^{96}$

92. See id. at 121-22, 125-26 (explaining that international prisoners are generally "incorporated into domestic prison populations[,]" where they are evaluated under the Presidents' discretion and offered rehabilitation programs of the State).

93. Id. at 119

94. See, e.g., Rome Statute, supra note 4, art. 106(1) ("The enforcement of a sentence of imprisonment shall be subject to the supervision of the Court and shall be consistent with widely accepted international treaty standards governing treatment of prisoners.”).

95. See Holá \& van Wijk, supra note 2, at 118-22 (differentiating between European countries like Norway, where inmates are housed in smaller facilities, usually including an individual prison cell, and Italy or France, where inmates generally face issues related to overcrowding and are housed in shared prison cells).

96. See id. at 120 (detailing that one ICTY convict in Finland has been allowed to serve his sentence in an "open prison," described by the author as "a facility without any walls"). 
One common feature of all international convicts, excepting the two ICC convicts, is that they have been designated to serve their sentences in locations far from the international convict's home nation. ${ }^{97}$ The SCSL convicts housed in Rwanda are nearly 3,000 miles from home. ${ }^{98}$ Even for the wealthiest individuals, opportunities to maintain relations with friends and family members imprisoned 3,000 miles away require a choice of relocation to an unfamiliar country or constant travel, which carries burdens of both time and expense. ${ }^{99}$ As previously mentioned, the cooperating states model has resulted in seventeen different European states willing to accept ICTY convicts (thirteen of which are actually housing prisoners) and two African states, Mali and Benin, willing to accept ICTR convicts (roughly 2,700 miles from Rwanda). ${ }^{100}$ In Europe, ICTY convicts are often integrated into the local prison population and serve side by side with individuals convicted of domestic crimes. ${ }^{101}$ SCSL convicts, in contrast, due largely to financial support from the Netherlands, have uniformly been placed in a special prison wing in Rwanda (a location nearly 3,000 miles

97. See id. at 118 (stating that the "majority of ICTR prisoners" are designated to serve their sentences in Mali and Benin, and SCSL prisoners are designated to serve in Rwanda); see also Mulgrew, supra note 28, at 385-86 (noting the "very real risk that international sentences of imprisonment served in a decentralized system may be excessively isolating").

98. See Holá \& van Wijk, supra note 2, at 118 (explaining that although the SCSL entered into an enforcement agreement with four countries, all convicts except one are serving their sentences in Rwanda).

99. See Jessica M. Kelder et al., Rehabilitation and Early Release of Perpetrators of International Crimes: A Case Study of the ICTY and ICTR, 14 INT'L CRIM. L. REV. 1177, 1190 (2014) ("As it is more difficult for families to visit, convicts complain that is it difficult to maintain close contact with relatives or partners."). Special rules relating to visits have, however, been put in place for some international convicts, but, like all other instances of imprisonment, vary from country to country. See Holá \& van Wijk, supra note 2, at 120 (explaining that "national authorities may provide special treatment for international prisoners," such as Norway or France, which allow special arrangements for visiting hours "to allow the prisoners to spend as much time as possible with their family within the limited timeframe available").

100. Holá \& van Wijk, supra note 2, at 117-18.

101. Id. at 120 . 
from Sierra Leone) and are kept separated from domestic inmates. ${ }^{102}$

Unlike domestic prisons, which can also be a great distance from one's village or town, the cooperating states model requires that family members traverse borders, not simply miles. And, for those imprisoned on the African continent, the distances between "home" and the prison facilities in Mali, Benin, and Rwanda are close to 3,000 miles away. ${ }^{103}$ For some international inmates and their families, separation covering such vast distances has endangered the continuation of meaningful family relations. ${ }^{104}$

Another common feature under the status quo for individuals serving their sentences abroad is that the host countries often have different languages, cultures, and customs. ${ }^{105}$ In nearly every case, it is unlikely the international convict or his or her family will speak the language of the enforcing state, which can make communicating with guards, physicians, spiritual advisors, and prison staff problematic. Language shortcomings further limit an international convict's ability to participate in rehabilitation programs, including educational opportunities or training programs. ${ }^{106}$ Such linguistic issues may even impair a family's ability to familiarize

102. Id. at 118; see also Distance from Rwanda to Sierra Leone, DistanceFromTo, $\mathrm{http} / / / \mathrm{www}$.distancefromto.net/distance-from/Rwanda/to/Sierra+Leone (last visited Mar. 27, 2016) (calculating the distance between Sierra Leone and Rwanda at 2,957 miles). The lone SCSL exception for sentencing purposes has been Charles Taylor. Holá \& van Wijk, supra note 2 , at 118 . His unique situation is discussed in the text more fully below.

103. See Holá \& van Wijk, supra note 2, at 118 (explaining that the ICTR sends the "vast majority" of Rwandan convicts to Mali and Benin to serve their sentences, and that the SCSL sends "[a]ll its [Sierra Leone] convicts" to Rwanda to serve their sentences).

104. See, e.g., id. at 120 (detailing a prisoner in France who "was never visited by his family for four and a half years... due to practical obstacles such as costs of travelling and housing or visa requirements").

105. Id. at 118 .

106. See Mulgrew, supra note 28, 389 (observing that participation in prison programs "requires a high degree of competency in the national language of the enforcing state"); Kelder et al., supra note 99, at 1190 (underscoring that "language barriers cause problems such as difficulties in understanding prison regulations, inability to participate in work or education programmes [and] problems in communicating with other prisoners, prison staff or the outside world"). 
itself with the prison rules, thereby limiting or hampering visitation and communications. ${ }^{107}$ If educational classes are offered only in the enforcing state's language, which most are, the international convict may find him or herself without access to otherwise available classes. ${ }^{108}$ The inability to communicate an inmate's basic needs on a regular basis places that individual at a serious handicap during his or her incarceration. ${ }^{109}$ Further, unless the prison provides individualized rules and regulations tailored to the inmate's native language, he or she may be unable to read governing policies or easily file a complaint or request services due to linguistic barriers in prison forms and policies. Even if a complaint is raised or a hearing held, unless the inmate is provided an interpreter, he or she may be at a severe disadvantage during the proceedings, particularly in relation to domestic prisoners.

The contrast is stark between the World War II tribunals, which housed inmates in two prisons where inmates spoke a common language, and the modern cooperating states model. ${ }^{110}$ At Nuremberg and Tokyo, convicts remained in their home countries, close to their families and with a familiar culture and language. ${ }^{111}$ The modern system jettisoned a local confinement

107. See Mulgrew, supra note 28, at 390 ("Though the procedures for arranging visits in enforcing states are public, relatives may not speak the languages in which the literature is published."); Kelder et al., supra note 99, at 1190 (finding that "language barriers cause problems such as difficulties in understanding prison regulations," which inhibit the communication between prison staff and family members wanting to visit or maintain close contact with convicts).

108. See Mulgrew, supra note 28, at 389 (illustrating that prisoners without a "high degree of competency in the national language of the enforcing state" will be less likely to participate in the programs); Kelder et al., supra note 99, at 1190 (explaining how "language barriers" effectively "negatively impact] the prisoners' abilities to integrate in prison or rehabilitate").

109. See Penrose, supra note 5, at 641 ("One of the more important requirements of any prison setting, at least from a human rights perspective, is that inmates retain the opportunity to convey their needs and concern to prison staff.").

110. Penrose, supra note 15 , at $555 \& 555$ n.9.

111. The International Military Tribunal was established in Nuremberg, Germany "to prosecute and punish" Nazi political and military leaders and the International Military Tribunal for the Far East was created in Tokyo, Japan "to try and punish" Japanese political and military leaders. Milestones: 1945-1952: The Nuremberg Trial and the Tokyo War Crimes Trials (1945-1948), U.S. DEP'T OF STATE OfFICE OF THE HISTORIAN, https://history.state.gov/milestones/1945-1952/nuremberg (last visited Mar. 
approach, due, in part, to the fact that the tribunals were a United Nations' creation, established in nation states other than where the conflict arose, and are not the product of a group of conquering allies. While the practice directions for the international tribunals regularly state the Registrar shall address the familial relations and linguistic skills of a particular convict and further mandates that the President "shall take into account the desirability of serving sentences in States within close proximity or accessibility of the relative of the convicted person," these directions have proven to be of little benefit when only a handful of states have entered enforcement agreements with the tribunals. ${ }^{112}$

Exporting those who have been convicted by an international tribunal has proven no easy task. Róisín Mulgrew and others have argued that the cooperating states model exacerbates the conditions of confinement by sending the convicted war criminals to distant locations where the lack of family, friends, a common language or culture, and even familiar cuisine are notably absent. ${ }^{113}$ There is an element of isolation to these incarcerations as many international convicts are placed in foreign prisons without programs or support systems tailored to their language, culture, or circumstances. ${ }^{114}$

Even though international convicts often receive the benefit of higher living standards for their imprisonment, such protections come at the price of distance and isolation. ${ }^{115}$ These

31, 2016); see also Mulgrew, supra note 28, at 391 (finding that familial relations are obviously far easier to maintain if an individual is incarcerated in his home State).

112. MICT Practice Direction, Designation of State, supra note 74, ๆ 4(a), 4(e), 5; Rwanda Practice Direction, supra note 1, ๆ 3(i), 3(v), 4; Yugoslavia Practice Direction, supra note 1, ๆ 4(a), 4(e), 5; Sierra Leone Practice Direction, supra note 1, ๆ 4(i), 4(v), 5.

113. See, e.g., Mulgrew, supra note 28, at 385 (explaining SCSL prisoners receive less visits from family and may experience "socio-cultural isolation"); Kelder et al., supra note 99, at 1190 (explaining ICTY prisoners face cultural difficulties and receive fewer visits from relatives).

114. See Kelder et al., supra note 99, at 1190-91 (explaining the lack of rehabilitation programs tailored to international convicts).

115. See id. at 1190 ("Serving a sentence in a foreign country typically has a negative impact on the ability of prisoners to reintegrate into society as they become socially isolated in prison.”). A good example of this distinction is the domestic Rwandan prisoners housed in the same facility with the SCSL convicts, but living in a separate 
higher incarceration standards, which are based on key international human rights documents, though important, fall far short of equalizing the fact that the international convict is being housed in a location foreign to him in every conceivable sense of the word. ${ }^{116}$ For example, Charles Taylor, the only SCSL convict currently held outside of Africa, requested that he be imprisoned in Rwanda, where other international inmates are currently being held.117 After being sent to the United Kingdom and denied transfer to Rwanda, Taylor complained he was being denied "a right to family life" as his relatives were not granted visas. ${ }^{118}$ Taylor contended that a prison sentence in Rwanda would be safer for him and less expensive for his family. ${ }^{119}$ Finally, Taylor argued that his confinement to the hospital wing was "effectively in isolation" because he is "too much of a target and too vulnerable to be accommodated within the general prison population" of the Frankland prison in Durham, England where he is being held. ${ }^{120}$ Taylor's final plea for an African placement was the need to be located in a prison where he shared "a cultural affinity" with others. ${ }^{121}$ The RSCSL denied his request. 122

wing with different standards of living and protection. See Holá \& van Wijk, supra note 2 , at 120 (noting that African prisons contain an international wing). International prisons must be kept in a location where international prison standards are honored. See $i d$. at 118 (explaining that enforcement agreements require prisons to adhere to international standards). The same protection is not always afforded to domestic inmates. See id. at 120 (discussing the special international wing of the Rwandan prison).

116. See Holá \& van Wijk, supra note 2, at 131 (describing the unique circumstances foreign prisoners encounter despite protections provided by international law).

117. Liberia's Charles Taylor Prefers Rwandan Jail to UK, BBC NEws (Oct. 14, 2013), http://www.bbc.com/news/world-africa-24520489.

118. Taylor filed a lengthy motion with the Residual Court for the SCSL on June 13, 2014. Motion for Termination of Enforcement of Sentence in the United Kingdom and for Transfer to Rwanda 9 3, In re Charles Ghankay Taylor, Case No. SCSL-03-01-ES (June 13, 2014).

119. Id. ๆๆ 5, 37-38.

120. Id. ๆ 4.

121. $I d$. $\mid 55$.

122. In re Charles Ghankay Taylor, Case No. SCSL-03-01-ES, Decision on Charles Ghankay Taylor's Motion for Termination of Enforcement of Sentence in the United Kingdom and for Transfer to Rwanda, \ 38 (May 21, 2015). 
Taylor's situation provides a concrete example of the cultural dimension and shortcomings relating to sentencing enforcement. The incident regarding Radislav Krstic, an ICTY convict, provides a similar example of the security shortcomings in the status quo. ${ }^{123}$

\section{Security}

Beyond limited access to family, friends, familiar foods, culture, and religious practices, there is evidence that security risks for these international convicts are higher when comingled with domestic inmates. ${ }^{124}$ Radislav Krstic, an ICTY convict of Serbian heritage, suffered severe injuries after being repeatedly stabbed by three British Muslim inmates seeking revenge for Krstić's crimes against Muslims. ${ }^{125}$ This episode, occurring within the Wakefield prison in Britain, underscores the security risk of placing international convicts within a domestic prison without physically isolating them. ${ }^{126}$ And, as these inmates are already culturally and relationally isolated, placing international inmates in physical isolation further accentuates the inherent flaws in a cooperating states model. Following the Wakefield stabbing, Krstić was transferred back to the United Nations Detention Unit in the Hague to await reassignment to another cooperating state. ${ }^{127}$ Krstić remained at the Hague Detention Unit for nearly two years before Poland agreed, in

123. See Martin Wainwright, Srebrenica General's Attackers Get Life for Revenge

Stabbing in Prison, GUARDIAN (Feb. 21, 2011, 12:09 PM), http://www.theguardian.com/uk/ 2011/feb/21/srebrenica-general-revenge-prison-attack (explaining that Krstić was attacked and had sustained severe injuries in a high security British prison).

124. See Mulgrew, supra note 28, at 376-77 (explaining security risks concerning international prisoners).

125. Wainwright, supra note 123.

126. See Mulgrew, supra note 28, at 385 (explaining that the nationality of and length of sentences for international convicts may result in a high security classification because enforcing states want to prevent such prisoners from being harmed).

127. Prosecutor v. Krstić, Case No. MICT-13-46-ES/IT-98-33-ES, Order Designating the State in Which Radislav Krstic Is to Serve the Remainder of His Sentence (July 19, 2013), http://www.icty.org/x/cases/krstic/presord/en/130719.pdf. 
May 2013, to receive Krstić pursuant a December 6, 2012 Polish court order. ${ }^{128}$

The potential security issues only compound the limitations of the cooperating state model. Not only may inmates fear being sent to a distant and unfamiliar location, there is the added fear, at least for some, that other inmates within the host state will learn of their crimes and seek to inflict injurious retribution. Krstić experienced this fear and sustained injuries while housed in Britain. Charles Taylor voiced this fear, though the SCSL discounted his pleas, keeping him imprisoned in Britain. ${ }^{129}$ Interestingly, the 3,000 mile distance between England and Sierra Leone is equivalent to the distance separating Taylor's desired placement in Rwanda from Sierra Leone. But, as Taylor's request indicates, it is not merely distance that exacerbates a sentence, but also family relations and security concerns. When assessing the best host country for a particular inmate, as we have seen with Krstić, issues relating to the international convict's security should be an integral part of the sentencing decision.

\section{Rehabilitation, Release, and Reintegration}

A fourth shortcoming with the status quo is the uncertainty regarding early release and the absence of appropriate rehabilitation and reintegration programs in enforcing states. ${ }^{130}$ Because the current model relies on cooperating states and

128. See id. (explaining that Poland agreed to received Krstić). Poland entered into an Enforcement Agreement with the ICTY on September 18, 2008. Agreement Between the Government of the Republic of Poland and the United Nations on the Enforcement of Sentences of the International Criminal Tribunal for the Former Yugoslavia, Pol.-U.N., Sept. 18, 2008, 2605 U.N.T.S. 177.

129. Motion for Termination of Enforcement of Sentence in the United Kingdom and for Transfer to Rwanda - 4, In re Charles Ghankay Taylor, Case No. SCSL-03-01-ES (June 13, 2014). In re Charles Ghankay Taylor, Case No. SCSL-03-01-ES, Decision on Charles Ghankay Taylor's Motion for Termination of Enforcement of Sentence in the United Kingdom and for Transfer to Rwanda, 38 (May 21, 2015). (explaining that a special Trial Chamber appointed by RSCSL President Justice Philip N. Waki denied Taylor's motion in January 2015).

130. See Holá \& van Wijk, supra note 2, at 125 (explaining that there is a lack of clear assessment criteria regarding the early release of international prisoners); see also Kelder et al., supra note 99, at 1202 (explaining how early release and rehabilitation programs could be improved). 
utilizes local law, in combination with tribunal consultation, for determining early release, international convicts with identical sentences may be subject to differing rules regarding early release. ${ }^{131}$ Mulgrew notes the shortcoming with this approach: "A system that places the trigger for release eligibility with enforcing states lacks certainty and creates the potential for discrimination due to the variation between the different domestic laws." 132

In contrast to early release, the issue of rehabilitation, apparently relevant to the ad hoc tribunals in sentencing, has largely been overlooked in international enforcement. ${ }^{133}$ Under the status quo, international tribunals delegate rehabilitation assessments, both testing and reporting, to domestic prisons that have little experience working with those convicted of genocide, war crimes and crimes against humanity. ${ }^{134}$ As Kelder, Holá, and van Wijk explain,

The fact that the tribunals are not actively involved in the enforcement of sentences means that the [tribunal] President relies heavily on information provided by third parties .... Although enforcement states have not been given any guidance on how to rehabilitate international prisoners, the President typically trusts their reports about a convicts' behaviour in prison and follows their advice in relation to the prisoner's level of rehabilitation. ${ }^{135}$

To delegate imprisonment of war criminals to enforcing states whose penal policies target more ordinary criminals seems

131. See S.C. Res. 1966, supra note 19, art. 26 (explaining that each State uses its own rules when deciding whether to pardon a prisoner and then notifies the MICT accordingly).

132. MULGREW, supra note 15 , at 57 .

133. See Kelder et al., supra note 99, at 1179 (contending that rehabilitation has been "entirely neglected by academia and practitioners alike").

134. See id. at 1193-94 (observing that the tribunal "President seems to do little to critically asses the underlying sources submitted [by enforcing states] to demonstrate prisoners' rehabilitation").

135. Id. 
incongruent with the desire to treat international convicts similarly. ${ }^{136}$ Inconsistencies in treatment will inevitably occur.

Mulgrew further observes that "the enforcing state is under no obligation to make connections with post-release services in third states," thus limiting opportunities international convicts have for reintegration. ${ }^{137}$ And, the basis for release hinges, at least partially, on the cooperating state's domestic structure for early release. 138 If rehabilitation entails reintegration into society, an international prison with personnel targeting the particular crimes covered - genocide, war crimes and crimes against humanity - will far better address the unique nature of such crimes and the motivations that lead otherwise ordinary individuals to commit such extraordinary acts. ${ }^{139}$ Kelder, Holá, and van Wijk assert that

International crimes... are not committed by abnormal (deviant) and extraordinary people, but are instead first and foremost characterized by the fact that perpetrators commit crimes in abnormal and extraordinary circumstances. [Thus,] conventional rehabilitation programmes developed for deviant individuals aimed to reintegrate them back into society and to facilitate a crime-free life are not appropriate for international prisoners. ${ }^{140}$

Without a permanent prison and a system coordinating parole or probation, international convicts are, in the most real sense, merely warehoused in domestic prisons. ${ }^{141}$ International inmates serve their time and, once they are either scheduled for release or released they are given little to no reintegration

136. See id. at 1196-97 (claiming that international criminals, because of the large-scale crimes they commit, are fundamentally different than ordinary criminals).

137. Mulgrew, supra note 28, at 390.

138. See Holá \& van Wijk, supra note 2, at 113 (explaining that the imprisonment of an international prisoner is governed by the law of the enforcement state).

139. See Kelder et al., supra note 99, at 1196-97 (discussing how persons who commit international crimes tend to come from deviant societal contexts).

140. Id. at 1197.

141. See, e.g., Mulgrew, supra note 28, at 390 (explaining that international convicts cannot "avail themselves of opportunities designed to enable prisoners 'to look for work, to make contacts with social services and to prepare for freedom"'). 
efforts dedicated to their successful return into society. ${ }^{142}$ There is generally no continued oversight or custodial supervision. ${ }^{143}$ Early release, in the current international context, typically means absolute freedom. The notable exception appears to be the RSCSL's approach granting conditional release. ${ }^{144}$ However, in some instances, early release means an inability to return home or elsewhere. ${ }^{145}$ The individual may no longer be behind bars, but neither is he or she necessarily free to return to their pre-incarceration life. ${ }^{146}$

Under most domestic prison systems, inmates scheduled for release go through a process to prepare them to re-enter society, which may include graded reductions in security and increased opportunities for self-sufficiency. ${ }^{147}$ Most domestic prison systems maintain a programmatic approach to early release, be it probation or some other form of reintegration that retains some level of continuing oversight of the prisoner. ${ }^{148}$ But, under the current system of cooperating states model where international convicts are sent to distant locations to serve their sentences, such domestic programs are generally not available to international inmates set to leave the enforcing state upon release. ${ }^{149}$ As Kelder, Holá, and van Wijk observe, "[i]n contrast to the domestic jurisdictions, the practice of setting conditions

142. See id. (noting that under the current system, "it seems unlikely that enforcing institutions will be able to provide meaningful support to international prisoners preparing for return to society").

143. Holá \& van Wijk, supra note 2, at 129 .

144. SCSL Practice Direction, Early Release, supra note 74, pmb.

145. Holá \& van Wijk, supra note 2, at 129-30 (reporting on the varied outcomes international prisoners face upon release, including at least one example where an international prisoner, Erdemovic, was placed in a witness protection program and given a new identity and several others where ICTR convicts were placed in a "safe house" in Tanzania upon their release).

146. See id. (providing numerous examples of life after incarceration).

147. See U.N. OfFICE ON DRUGS \& CRIME, HANDBoOK ON THE INTERNATIONAL Transfer of Sentenced Persons 9, 11 (2012) (emphasizing the attention paid to rehabilitation and noting the availability of self-sufficiency aimed practices, such as "prison leave and other authorized forms of exits from prison," that are available in domestic prison systems).

148. Holá \& van Wijk, supra note 2, at 129.

149. See id. (describing life after release for international convicts as a time when the "prisoners are literally 'off the radar"). 
upon early release - e.g., no repetition of offenses - does not exist for ICTY and ICTR convicts." 150

Although early release for international convicts is evaluated by assessing domestic law, and relies largely on local assessment regarding rehabilitation, that same domestic law does not provide programmatic support or continuing oversight for the international convict. ${ }^{151}$ Lacking any monitoring system for released international convicts, excepting the RSCSL conditional release program, "the prisoners disappear from the tribunals' radar and are not of their concern." 152 Kelder, Holá, and van Wijk provide troubling case examples where failure to monitor those released by international tribunals have seemingly undermined the values of international criminal justice, with the perpetrators largely flaunting their freedom and retracting any claims of remorse. ${ }^{153}$

To ensure that sentences are being uniformly served under similar conditions and that rehabilitation and reintegration are made part of the sentencing enforcement process, a permanent prison with attendant personnel, parole officers, and consistent rules relating to rehabilitation and early release is needed. If all international convicts are being sentenced for similar crimes, or at least crimes of a similar magnitude, there should be standardized governing principles put in to operation based on the underlying crime, independent from the nation state receiving the inmate for sentencing enforcement purposes. The current ad hoc approach to imprisonment leads to unacceptably inconsistent approaches toward rehabilitation and early release. ${ }^{154}$

150. Kelder et al., supra note 99, at 1198.

151. Id. at 1193-94.

152. Kelder et al., supra note 99, at 1198 (internal quotation marks omitted).

153. See id. at 1199-1200 (detailing the post-release behavior of ICTY convicts Biljana Plavsic and Veselin Sljivancanin).

154. See MULGREW, supra note 15, at 57 ("A system that places the trigger for release eligibility with enforcing states lacks certainty and creates the potential for discrimination due to the variation between the different domestic laws."). 
Reintegration, both through graded release and continuing oversight, is a vital component of penal policy. ${ }^{155}$ The current model omits critical rehabilitation and reintegration structures and, thus, provides additional support for concentrating the sentencing enforcement process in an international prison system.

\section{OBSTACLES TO CREATING AN INTERNATIONAL PRISON}

The creation of an international prison system, much like the creation of an international court system, presents both costs and risks. The ICC follows several ad hoc international tribunals and holds the promise of a lasting solution to addressing international crimes. These initial court efforts at the ICTY, ICTR, SCSL, and ICC have all incurred extensive financial costs and burdens. ${ }^{156}$ And, because the work of the tribunals created long prison sentences that have outlasted the ad hoc tribunals, there are the additional costs related to the MICT and the RSCSL. 157 Thus, the ad hoc tribunals may have ceased operations, but the sentences and cases still remaining have required the creation of secondary or residual courts to slowly winnow away at the remaining work still to be done. The RSCSL projects that it may need to remain in operation until 2055 to finalize all its work relating to the enforcement of sentences. ${ }^{158}$

155. See U.N. OfFiCE ON Drugs \& CRIME, supra note 147, pt. III. A. (noting that the "essential aim of a penitentiary system is the reformation and social rehabilitation of prisoners").

156. See, e.g., Davenport, supra note 10 (raising the question whether the "I.C.C. is simply too expensive and ineffective to justify"); Gabriël Oosthuizen \& Robert Schaeffer, Complete Justice: Residual Functions and Potential Residual Mechanisms of the ICTY, ICTR and SCSL, 3 HAGUE JUST. J. 48, 59 (2008) ("The costs associated with the ICTY, ICTR and SCSL are high ....").

157. See S.C. Res. 1966, supra note 19, art. 1 (noting the additional costs associated with implementing the MICT); Agreement to Establish RSCSL, supra note 66, art. 3 (granting the Parties and the oversight committee the option to "explore alternative means of financing").

158. See The Mandate of the Residual Special Court for Sierra Leone: Background, supra note 66 (noting that as part of its ad hoc functions, the RSCSL "will have the authority to manage requests for review from convicted persons and this function may extend until 2055”). 
Judges, courtrooms, and court staff are expenses that must be borne if an international court system is to function effectively. Time has provided great experience, including a demonstration of modest cooperation from nation states. From a post-World War II version of "victor's justice" to the modern ICC, which covers nearly the entire world, international courts have evolved slowly but deliberately. Perhaps then, as the world community considers the financial cost of erecting and maintaining a permanent international criminal court, 159 thought should be given to erecting and maintaining a true, permanent prison facility for international convicts.

The first obstacle will be location. Great consideration should be given to those countries and locations where construction might not be required from the ground up. Rather, a location - one that is centrally located in a politically stable country with a solid record regarding human rights should be selected to refine an existing structure capable of providing the highest level of service and security to international convicts. But, a complicating factor in the analysis for creating a single prison location is that our world is so enormous and diverse. What one country could house such distinctive populations supporting numerous languages, cultures, and religions? These are troubling questions that have not yet been adequately analyzed or discussed by scholars, lawyers, and judges.

\section{A. The Costs}

Much like the actual costs borne by the ICTY, ICTY, SCSL, and ICC, there will be actual costs borne by an international prison system, one involving building maintenance, staffing, and programmatic expenditures. If the convicts at the former ad hoc international tribunals or the ICC are to be held in a single location or in regional facilities overseen by a single supervising entity, a physical prison structure must either be built or remodeled. These costs involve real money, including bricks and

159. See ICC Holds Groundbreaking Ceremony for Permanent Premises Construction, supra note 14 (explaining the funding for the permanent ICC in the Netherlands). 
mortar. In addition, there will be staffing needs, from wardens, to guards, to medical and religious personnel. Building and maintaining a prison is a costly endeavor. Some country, entity, international organization, or combination thereof will need to absorb the costs associated with both constructing and running an international prison.

There are costs of outfitting the inmates, creating and printing prison rules, providing guards and prison staff capable of communicating with the inmates, medical personnel and facilities, access to psychological and psychiatric services, educational and career training, access to religious and spiritual advisors, and food services capable of feeding a variety of dietary needs, and security.

And, much like the evolution from Spandau Prison in Germany, where the Allies oversaw their convicts in a conquered country, ${ }^{160}$ to a system where cooperating states host international convicts, the trajectory suggests a need for consolidation - either to a single international prison unit or, perhaps, regional units existing under a single international prison umbrella. As set forth above, there are many notable shortcomings in the cooperating states model, from the obvious and consistent lack of cooperation to issues stemming from early release and lack of rehabilitation programs. Additionally, the distance, linguistic, and security concerns are already noted as issues under the status quo.

\section{B. Safety and Security Issues}

In addition to real financial costs, there are safety risks involved with creating an international prison. First, the risk of placing all high level international criminals in a single location, potentially with regional facilities, could increase security concerns for individuals displeased with tribunal outcomes or international justice. Because the ICC will be handling only those individuals whose crimes merit international attention, it

160. See Wolfgang Saxon, Spandau Prison: Hess's Lonely Dungeon, N.Y. TimeS (Aug. 18 1987), http://www.nytimes.com/1987/08/18/nyregion/spandau-prison-hess-slonely-dungeon.html (noting that Spandau was "the last vestige of postwar four-power rule in Germany" whereby guards from Britain, France, the Soviet Union, and the United States oversaw the prison). 
can be expected that the crimes will stem, like those heard before the ICTY, ICTR, and SCSL, from internal conflicts and wars with continuing unrest in the home country. Such grouped incarceration might embolden members of one of the warring factions, or others, to target an international prison or international prison employees. What country or countries would be willing to assume the risk of housing the worst of the worst, collectively, and withstand the constant security threat such inmates pose? Is the concentration of the world's most notorious international criminals in a single location a truly workable solution? While this concentration has already occurred uneventfully, at least from a security perspective, in the Hague and Tanzania, these distant locations provided some measure of security for those angry in Yugoslavia, Rwanda or, most recently, the Democratic Republic of the Congo.

On the other hand, the question of security might also be more easily answered in a single location where adequate exterior and interior security may actually provide greater protection to those convicted of the worst crimes known to humanity. If a single location could be selected, the concentration of individuals all posing a high security risk could be collectively addressed to minimize security breaches. Further, the location itself could provide heightened security protections against outside threats. From island selections to remote areas within numerous nation states, the issue of security poses both a risk and potential advantage in terms of housing war criminals and international convicts.

The security question naturally raises, and is tied to, the related issue of location. How does the international community address the risk in deciding where such international prison, or regional prisons, might be built and maintained? Will there continue to be European and African overrepresentation? The variation of prison facilities between poorer countries and wealthier, industrialized countries is relevant from a human rights perspective. But, giving emphasis to wealthier countries could compromise certain individuals' access to family, legal counsel, religious traditions, cultural institutions and dietary requirements by placing a prison outside the realm of travel for many families. While an international prison may not resolve these "location" issues, at least all international convicts will be 
similarly disadvantaged and their families on notice of where they must travel. And, if a single location is ultimately selected, families confronting visa requests and housing needs will face similar procedures for securing visits.

While location becomes relevant to ensuring safety, any selected location cannot be so remote that family, friends and others, like legal counsel, are prevented from visiting and maintaining relations with the inmate. If a new, truly international prison is to be constructed, efforts must be made to protect against recreating the flaws existing in the current system - such as isolation from friends and family. The most centralized location, with adequate transport options (bus, rail and air) should be sought. Regardless of location, there must be efforts made to make an international prison truly transnational and capable of hosting a range of nationalities, languages, religious traditions and dietary needs.

Security is a major issue, presenting both potential risks and rewards, but other demands - particularly those exposed under the status quo - will quickly require attention.

\section{Creating Uniformity Among Diversity}

The goal of an international prison must be to provide a standardized global response to a universal problem. An international prison will, eventually, have inmates from across the world, bringing together a cacophony of languages and cultures. The creators of an international prison will have to work diligently to ensure that no matter who is incarcerated, acceptable meals, rules and religious options are available to all. There can be no superior cultural norm - no Westernization or Easternization of treatment. There must be cultural sensitivity and, yet, common norms. This delicate balance may actually be the most daunting task facing the creation and maintenance of an international prison.

In some countries, chain gang or work requirements exist. In others, the focus of incarceration may be rehabilitation or reintegration into society as a law-abiding, even educated, citizen. But what is the penal goal of international justice? Will inmates receive funds to purchase items at a commissary? Will inmates be expected to work in jobs at the prison, as barbers, 
cooks and lawn care personnel? What standards of care, beyond the United Nations minimum standards, will govern? And, equally important, who will choose which norms govern? This author would delegate entirely the task of assessing both penal policies and creation of an international prison to one entity, preferably one similar to that presented below.

The answers to these questions are still evolving. There appears to be a deep incongruity between the lengthy sentences issued by international tribunals with sentences served in unfamiliar countries and the goal of rehabilitative urged by human rights documents. This article does not allow for a more thorough consideration of the ultimate penal policies an international prison should adopt, but does note that centralizing international convicts in a single prison will undoubtedly lead to more fair and consistent treatment with a more uniform approach to penal policy and does argue for creation of a new entity to oversee the process.

To ensure uniform treatment for all international convicts and in a move toward creating a permanent international prison, I recommend the creation of an International Prison Advisory Panel (IPAP) staffed with prison experts from a fair cross section of the globe. The IPAP should be integrated into the current ICC and MICT bodies, thereby informing the current structure where enforcement state designations and early release decisions are made by the ICC President or appropriate RSCSL Chamber. The IPAP should address all inmate issues arising from current internationally focused courts and residual mechanisms, such as the ICC, the MICT, and RSCSL. The IPAP should prioritize the creation and maintenance of an international prison system as its focus. The IPAP's initial charter should establish goals for creating a permanent prison, creating standardized penal policies for international convicts and for staffing both a prison, inclusive of diverse rehabilitation programs, and a standardized early release program for each respective court (i.e. one standardized program for the ICC and another for the RSCSL).

The IPAP should be funded by a reliable source, either the United Nations or the ICC. If funded by the United Nations, the IPAP could also be governed by the United Nations and located 
at the New York Headquarters or, in the alternative, wherever the permanent prison location is. If the ICC becomes the source of funding, the IPAP can be housed at the Hague or, again, wherever the ultimate site of the permanent prison is. The IPAP should be given input in the enforcement of international sentences flowing from the ICC or any ad hoc tribunals as the international community weans itself from the cooperating states model and reliance on state input. While the current legal structure does not permit complete delegation, this author believes the legal framework should be amended to provide IPAP with some role in sentence enforcement, including input regarding early and conditional release.

IPAP is simply a concept, much like the Rome Statute was two decades ago. To bring this idea to fruition would undoubtedly require both reassessment and amendment to governing documents binding the international tribunals. But, to be effective, this idea requires complete incorporation into the status quo, not merely a subsidiary existence adding to the deficiencies of the status quo.

In terms of IPAP composition, there should be at least one representative from Africa, Asia, Europe, the Americas, the Middle East and Russia or the Slavic countries. It would be advisable to include those who have had experience dealing with the housing of international convicts from the ICTY, the ICTR and the SCSL. Countries refusing ICC membership or jurisdictional application before the ICC should not be permitted on the panel. Instead, countries whose citizens might be vulnerable to international prosecution before the ICC and other ad hoc tribunals should have both a voice and potentially representation on the IPAP. The purpose of the IPAP will be to ensure consistent treatment among internationally sentenced individuals. At present, that task of ensuring fair and humane treatment is shared by numerous entities and borne, largely, by the host nation states themselves. Because sentencing enforcement is an integral part of the criminal prosecution process, including issues relating to early and conditional release, the IPAP should be included in the process to ensure that sentence enforcements become more uniform, predictive and fair. 
The IPAP should have a minimum of seven and a maximum of nine individual members, with a goal of securing race, gender and religious diversity. Terms should be strictly limited to no more than three years so that no one individual or country has a hold on the ideas being discussed or programs pursued in a permanent prison facility for the international community. The terms among the panel should be staggered so that there is some level of continuity among the panel. For example, if the panel has nine members, each year there should be three positions that become vacant for three new members. An IPAP would ensure a continuing commitment to prison oversight and improvements as international law evolves.

The advantages of creating an IPAP is that this group could be responsible for all facets of creating, and ultimately, overseeing an international prison, from budgeting to prison inspections to determining policies and procedures for international convicts. Further, because past sentences issued by the ICTY and ICTR were not always consistent, IPAP should provide some guidance in the sentencing enforcement process from state designation to early release, even if this guidance is only placed in IPAP Advisories. The IPAP could further work with the ICC, the MICT and the RSCSL to ensure that the international community is developing an actual penal policy for those found guilty of war crimes and crimes against humanity, not simply perpetuating the ad hoc approach to the enforcement of sentences. IPAP's greatest contribution to international criminal law, in fact, could be creating the first truly international penal policy governing international crimes. This article does not tackle the far more difficult question of what the international penal policy should be, involving choices between deterrence, retribution and rehabilitation, among others, and would think it advisable to delegate such Herculean task to the IPAP. At present, the focus appears to be on imprisonment for a term rather than imprisonment for a purpose. ${ }^{161}$ Creating and utilizing an IPAP could help properly place imprisonment in the larger context of an international criminal system, as opposed to

161. See generally Holá \& van Wijk, supra note 2, at 111-12, 125 (noting the general lack of uniformity of importance placed on the rehabilitation of international criminals, and the generally long sentence terms they serve). 
merely warehousing convicted individuals, thereby improving on the current free-floating, ad hoc system.

\section{CONCLUSION: THE BENEFITS OF AN INTERNATIONAL PRISON OUTWEIGH THE RISKS}

One must ask why little progress has been made regarding the creation of an international prison. Is the issue safety, finances, building location(s) or simply lassitude? Has any government, committee or non-governmental organization undertaken a proper study balancing the benefits versus risks of creating an international prison? We have a clear need to address the issue of punishment and imprisonment now that we have a permanent court. ${ }^{162}$ And, the question of where these international convicts will be housed moving forward is no longer merely a theoretical problem. The time for creating an international prison is upon us. We must act now. ${ }^{163}$ Creating an IPAP provides one vision of a potential solution.

The time has come for a permanent prison solution. We have an international criminal court. We need an international prison. Deterrence will be furthered if the cooperation among nations is both united and permanent. The ICC should be the starting point for a larger, more permanent approach to realizing the still unachieved promise of "never again." The world deserves an international criminal court that is capable of enforcing its judgments without relying on willing or cooperating states. Prison, for a court whose sentencing options are primarily focused on incarceration, should have been a starting point, not an afterthought. The time is ripe for an international prison if, in fact, we are committed to international justice, not merely prosecutions.

162. See Penrose, supra note 5, at 642 (noting that a permanent criminal court will require a permanent prison facility for placement of its condemned, who would best be served by the "utilization of regional facilities").

163. See Holá \& van Wijk, supra note 2, at 122 (noting that forty-five percent of all international convicts have been released); ICC Res. RC/Res.3, supra note 50, ๆף 1-2 (noting that the Resolution, while again calling on States to "indicate to the Court their willingness to accept sentenced persons[,]" also confirms that "a sentence of imprisonment may be served in a prison facility made available in the designated State through an international or regional organization, mechanism or agency"). 